\title{
Autonomy versus paternalism: will of the person or will of the collective?
}

\author{
Trajano Sardenberg ${ }^{1 *}$ (D), Reinaldo Ayer de Oliveira ${ }^{2}$ (1)
}

Spanish doctors Diego Gracia ${ }^{1}$ and Diego Capilla ${ }^{2}$ state, in separate texts, the gradual collapse of paternalism within doctor-patient relationships, which is, nowadays, called clinical relationships, involving several health professionals and the patient. In the 1960s, when values related to private management of the body, sexuality, life, and death begin to assume a fundamental role in people's life who demand respect for their wills and wishes, the autonomy or better, the respect to autonomy emerges from books and theory into a clinical relationship. Slow transformations, putting paternalism outside making autonomy the center of a clinical relationship, suffer an expressive increase in speed. The book by Beauchamp and Childress "Principles of biomedical ethics" 3 , 1979, establishes the principles of respect for autonomy, of non-maleficence, of beneficence and justice as marks for the practice and resolution of ethical conflicts and dilemmas within a clinical relationship, despite stating that there is no hierarchy among them, it reinforces denial of paternalism ${ }^{4}$.

In the real world, theory and practice are different. A patient with terminal and severe cancer who refuses surgery which causes more suffering and requests pain and well-being care represents a distressful situation yet easy to do so and which respects the patient's will. But, on the other hand, what about a patient with breast cancer who refuses conventional treatment and requires only homeopathy and acupuncture? Doubtlessly, the doctor's respect to a patient's autonomy, in such a case, is almost impossible, unless the doctor stops being human and acts only as an insensitive machine. When cases involve children, doctor's confusion and suffering are even worse. How to face parents who refuse treatments, with good curing chances, for their children? In such cases, society must act, within the law as well as in a convincing way.
Respect for people's autonomy in society cannot be total. If this were to be, it would be the chaos of a society without the limits of the law. The free will of Stuart Mills, in the 19th century, can only be practiced in a democratic and mainly responsible society. Within this context, several countries enact laws that obliges people to be careful. Seat belts in cars, as well as helmets for motorcycles, are classical examples. In countries where health services attend all people with no individual charge, such aspect is even more important. It's easy to understand. A person exercises his/her free will and does not wear a helmet on the motorcycle; suffers an accident with severe skull trauma and has all the treatment and support is paid by society. It is free will with no responsibility and lots of selfishness, followed by the thought that "I do whatever I want and if there is a problem the State takes care of everything including my family". Another situation of free will without responsibility and with lots of selfishness and opportunism is observed in people who live in large urban societies who do not take vaccines and do not vaccinate their children and rely on herd immunity, thinking that "others are at risk of vaccines, even if it's minimal, and my family and I are immunized. According to Battin et. al. in "The patient as victim and vector - ethics and infectious disease" ${ }^{6}, 2009$, therefore a decade before the beginning of the COVID-19 pandemic, discuss the limits of bioethics mainly concerning the principle of autonomy in severe infectious disease with rapid and wide dissemination.

Respecting the will of patients, of people, not only people but also social and group cultures within a democratic society, is not an easy task (within a totalitarian society people's autonomy does not exist), especially when such individual wills or even partially collective, conflict with rights and wills of the majority. Considering people's autonomy and collective interests is

\footnotetext{
'Universidade Estadual Paulista Júlio de Mesquita Filho, Faculdade de Medicina de Botucatu - Botucatu (SP), Brazil.

¿Universidade São Paulo, Faculdade de Medicina - São Paulo (SP), Brazil.

*Corresponding author: trajano.sardenberg@unesp.br

Conflicts of interest: the authors declare there is no conflicts of interest. Funding: none.

Received on November 08, 2020. Accepted on January 12, 2021.
} 
a gigantic goodwill task as well as negotiation. One of the difficulties is to establish who is going to speak up for the collective interest. Laws, a special kind of collective, isolated and unconvinced are ineffective in a democratic society. The guidelines and rules from government officials forcing the use of masks and prohibiting agglomerations during the current pandemic of the new coronavirus have not been followed by a large part of the population and the State is unable to apply punitive actions provided by law.

Kwame A. Appiah in his book "O Código de honra: como ocorrem as revoluçôes morais" (The honor code - how moral revolutions happen) explains the role of active intellectuals in the moral debate for promoting changes in customs, analyzing the end of duel practices in Europe, the aesthetic of small feet in Chinese women as well as African slavery in Americas. Appiah mentions that in China the small and deformed women's feet turned from aesthetic beauty and pride to shame and ugliness. Recently, intense action by international organizations, associated with intellectuals as the writer Mia Couto and local activists such as Theresa Kachindamoto, Mozambique proclaimed a law prohibiting marriage between girls and adults ${ }^{8,9}$. Due to the strength of the arguments, exhaustively explained, those behaviors considered normal and of high moral and aesthetic value are now considered by the majority of society as incorrect, coarse, and immoral. In Brazil, the campaign against smoking is an example of success, combining extensive scientific persuasion about the harmful effects of tobacco, laws which restrict its use, bans on advertising and strong economic tightening through high taxes. Perhaps the most important thing has been the emphatic message that smoking is no longer glamourous, making up a moral and aesthetic victory.

The ethics of paternalism, having someone determining what has to be done by patients and all people, disrespecting autonomy has no place in free democratic societies. Social experiences of such practice in recent human history when a group of people on behalf of the majority established what was right and wrong only succeded in totalitarian societies thus causing loss of freedom and enormous human suffering. The flexibility of autonomy should be the exception and the prevalence of collective interest must be sought through explicit arguments in society with scientific and especially moral, ethics, and spiritual approaches. The laws which may arise from this democratic process will certainly be closer to the wills of the people in our society.

\section{AUTHORS" CONTRIBUTIONS}

TS: Conceptualization, Formal Analysis, Investigation, Writing - original draft, Writing - review \& editing. RAO: Conceptualization, Formal Analysis, Investigation, Writing original draft.

\section{REFERENCES}

1. Gracia D. Pensar a bioética: metas e desafios. São Paulo: Loyola; 2010.

2. Capilla DJF. El nacimiento de la bioética. Madrid: Nueva; 2014.

3. Beauchamp TL, Childress JF. Princípios da ética biomédica. São Paulo: Loyola; 2002

4. Ferrer JJ, Álvarez JC. Para fundamentar a bioética: teorias e paradigmas teóricos na bioética contemporânea. São Paulo: Loyola; 2005.

5. Mill JS. Sobre a liberdade/a sujeição das mulheres. São Paulo: Companhia das Letras; 2017.
6. Battin MP, Francis LP, Jacobson JA, Smith CB. The patient as victim and vector: ethics and infectious disease. New York: Oxford University Press; 2009.

7. Appiah KA. O código de honra: como ocorreram as revoluções morais. São Paulo: Companhia das Letras; 2012.

8. Nações Unidas. Moçambique adere à iniciativa global para proteger meninas de casamentos precoces. Nova York: Nações Unidas; 2020 [cited on Nov. 02, 2020]. Available from: https:// news.un.org/pt/story/2020/03/1706901

9. Couto M. Lute como uma mulher! Facebook; 2020[cited on Nov. 02, 2020]. Available from: https://www.facebook. com/298257536887970/posts/2698756100171423/ 